KALAM, P-ISSN: 0853-9510 E-ISSN: 2540-7759

http://ejournal.radenintan.ac.id/index.php/KALAM

Volume 10, No. 2, Desember 2016, halaman 517 - 536

\title{
Membangun Toleransi \\ Dalam Perspektif Pendidikan Spiritual Sufistik
}

\author{
M. Akmansyah \\ IAIN Raden Intan, Lampung \\ m.akmansyah@ymail.com
}

\begin{abstract}
Abstrak
Despiritualisasi merupakan proyek modern yang menyerbu hampir ke semua lini penting kebidupan, tanpa kecuali mengenai toleransi. Toleransi sangat dibutubkan karena beragam macam perbedaan yang tak terbindarkan secara empiris ternyata rentan mengalami disintegrasi, dan berubah menjadi malapetaka intoleran. Manusia secara individual membutubkan toleransi sejati atau toleransi spiritual itu. Demikian pula masyarakat pluralis dan multikulturalis, karena kesejatian toleransi sekaligus berarti intensifikasi pengalaman spiritual. Toleransi spiritual yang dikembangkan oleh pendidikan spiritual sufistik akan menambabkan karakteristik lain. Sebab, tasawuf membimbing manusia menuju keharmonian dan keseimbangan secara total; mengajarkan toleransi, moderasi, bidup berdampingan secara damai dan nilai-nilai kemanusiaan. Artikel ini mencoba membuktikan, setidak-tidaknya secara konseptual, bahwa dalam pendidikan spiritual sufistik. Islam dapat mengambil perannya untuk menjawab tantangan-tantangan toleransi mutakbir.
\end{abstract}

\begin{abstract}
The spirituals' emptiness is a modern project that invaded almost all important spheres of contemporary life, including tolerance. Tolerance is needed in various inevitable tensions empirically susceptible to disintegration, and further turned into intolerance disasters. Everyone needs a true tolerance or spiritual tolerance, as well as the pluralist and multicultural society, so it
\end{abstract}


can be improved by activating inner life and intensifying spiritual experience. Spiritual tolerance developed by Sufi spiritual education will enrich other characteristics. Therefore, Sufism lead men to harmony life and balance in total; teaches tolerance, moderation, peaceful coexistence and increases human values. This article tries to prove, at least conceptually, that the Islamic Sufi spiritual education can take part to answer the challenges of tolerance in the present.

Key Words: Tolerance, Spiritual Education, Sufism

\section{A. Pendahuluan}

Toleransi bukan sekedar persoalan ilmiah yang menarik dibicarakan secara akademis, melainkan pula urgen untuk dipecahkan secara politis, sosiologis, kebudayaan, dan keagamaan. Hal ini karena sikap intoleran akan mengancam integritas masyarakat pluralistik, multikulturalis, dan membahayakan kehidupan bernegara. Akan tetapi, karena keterbatasan ruang dan waktu, tidak mungkin membahas semua urgensi tersebut dan basis argumentasinya di sini. Jika dikaitkan dengan dua variabel determinannya, yaitu agama dan negara, maka ada dua basis argumen toleransi. Pertama, keyakinan atau kepercayaan seseorang berasal dari kesadaran diri sendiri, yang tidak dapat diintervensi oleh kekuataan atau paksaan dari luar dirinya. Klaim-klaim kesadaran akan keyakinan atau kepercayaan sangat subjektif. Orisinalitas nilai tindakan individual, sosial dan kultural sepenuhnya bergantung pada keyakinan atau kepercayaan yang tumbuh dari kesadaran diri subjek (peyakin). Argumen ini berakar pada teologi Protestan. Kedua, pemisahan agama dan negara yang semakin menguat telah menimbulkan ide penting mengenai peran negara, yaitu mempertahankan tatanan sivil (civil order) ketimbang menyodorkan keyakinan atau kepercayaan kepada warga negara. Toleransi mesti ditumbuhkembangkan ke dalam semua keyakinan atau kepercayaan yang tidak mengancam tatanan publik (public order) dan otoritas pemerintah (government authority). ${ }^{1}$ Toleransi seolah-olah merupakan instrumen eksternal yang berasal dari negara dan

1John Horton dan Susan Mendus, "Introduction" dalam John Horton dan Susan Mendus (eds), Aspects of Toleration Philosophical Studies, (London and New York: Methuen, 1985), h. 2-3 
disematkan kepada setiap agama untuk membina kehidupan publik dan politis.

Argumen pertama mengandaikan sumbu toleransi horizontal; antar individu, antar komunitas, dan sebagainya, yang memiliki perbedaan keyakinan atau kepercayaan. Kesadaran diri dan orisinalitas keyakinan atau kepercayaan orang atau komunnitas lain merupakan syarat yang harus dimengerti oleh seorang atau kelompok toleran. Keharusan untuk mengerti pihak lain (the other) hampir menjadi norma sosial dan kultur toleransi. Argumen kedua mengandaikan sumbu toleransi vertikal. Netralitas negara terhadap semua keyakinan atau kepercayaan warga negara menjadi syarat mutlak toleransi. Netralitas negara mengandaikan bahwa negara tidak dapat menganut agama tertentu.

Kedua sumbu toleransi tersebut mirip dengan toleransi Pancasila seperti dimaksudkan oleh Soekarno (w 1970). Pancasila adalah argumen toleransi horizontal karena ia digali dari jati diri bangsa Indonesia yang pluralistik dan multikulturalis. Dalam pidatonya pada 1 Juni 1945, Soekarno mengatakan: "Marilah kita amalkan, jalankan agama, baik Islam maupun Kristen dengan cara yang berkeadaban. Apakah cara yang berkeadaban itu? Ialah hormat-menghormati satu sama lain." Pancasila adalah argumen toleransi vertikal karena negara berkewajiban untuk mempertahankan dan melindungi beragam macam agama, kepercayaan, atau keyakinan warga negara. Soekarno menegaskan: “... negara Indonesia satu negara yang ber-Tuhan."2 Negara berTuhan merupakan salah satu pembeda toleransi Pancasila dari toleransi liberal. Dengan demikian, Indonesia telah memiliki argumen--bahkan ideologi--toleransi yang ber-Tuhan dan terus dipertahankan hingga sekarang.

${ }^{2}$ Kutipan-kutipan langsung di atas berasal dari pidato Bung Karno yang semula disampaikan secara lisan pada Sidang Dokuritu Zyunbi Tyoosakai atau Badan Penyelidik Usaha Persiapan Kemerdekaan (BPUPK), 1 Juni 1945, tetapi mendapat sambutan luar biasa, dan kemudian dikenang sebagai hari lahir Pancasila. Transkripsi lengkap pidato Bung Karno dapat dilihat pada "Lahirnya Pancasila" Pidato Pertama Pancasila Diucapkan Bung Karno di Depan Dokuritu Zyunbi Tyoosakai 1 Juni 1945 dalam http://www.gmni.or.id/mediafiles, diakses tanggal 15 November 2016 
Mengapa toleransi yang ber-Tuhan itu seolah-olah menjadi diskursus dan tema kontemporer? Salah satu jawabannya ialah karena tantangan yang dihadapi oleh kedua sumbu tersebut telah berkembang sedemikian rupa, baik secara teoritis maupun praktis. Konflik yang bernuansa SARA (Suku, Agama dan Ras) pasca Orde Reformasi dan belum sepenuhnya memudar hingga sekarang merupakan tantangan praktis toleransi, yang memang seharusnya segera diselesaikan secara teknis. Tantangan serius lainnya, seiring dengan perkembangan pola kehidupan sekuleristik dan pragmatis, ialah munculnya upaya untuk meniadakan unsur dan argumen spiritual keagamaan dalam membangun toleransi. Ada anggapan bahwa dimensi spiritual yang berbasis pada agama tidak menumbuhkembangkan toleransi antar keyakinan atau kepercayaan. Alih-alih menopang kehidupan yang toleran, agama menyokong eksklusifisme, diskriminasi, dan intoleransi.

Penulis bermaksud mengoreksi anggapan despiritualisasi terhadap toleransi, dan mencoba membuktikan, setidak-tidaknya secara konseptual, bahwa dalam pendidikan spiritual keagamaan, khususnya tasawuf Islam, terdapat penanaman nilai-nilai toleransi dan argumennya yang khas, dan dapat direkomendasikan untuk menjawab tantangan-tantangan toleransi mutakhir. Asumsi yang penulis pegang, tetapi tidak mungkin didiskusikan di sini, ialah semakin masyarakat mengalami proses spiritualisasi, semakin mudah menumbuhkan sikap toleran pada masyarakat tersebut. Penulis menyebutnya toleransi spiritual.

\section{B. Toleransi Spiritual}

Dalam paham liberal, toleransi berarti negara menjamin pilihan bebas (freedom of choice) individu sebagai warga negara, entah pilihan keagamaan, moral, maupun pilihan-pilihan personal lainnya. Toleransi liberal bergandengan dengan pluralisme yang didasari oleh pandangan koeksistensi pilihan bebas dan non diskriminasi. ${ }^{3}$ Gandengan ini menyebabkan masa depan pluralisme bergantung pada eksistensi negara yang mengakomodir asas-asas liberalistik, setidak-tidaknya negara yang mendasarkan kebijakan publiknya

${ }^{3}$ Anna Elisabetta Galeotti, Toleration As Recognition, (Cambridge: Cambridge University Press [Virtual Publishing], 2003), h. 5 
pada asas non diskriminasi. Toleransi liberal akan sangat sulit memainkan peran efektif di negara teokratis, non-demokratis, dan berkecenderungan kuat untuk mengintervensi pilihan-pilihan personal warganya. Toleransi liberal tidak menginvestasikan harapan-harapannya kepada pertumbuhan spiritual keagamaan, karena memang basis argumen toleransi liberal bukan agama. Oleh karena itu, pengertian toleransi spiritual, yang mengandaikan argumentasi keagamaan, perlu dijelaskan.

Toleransi adalah sifat atau sikap toleran, yaitu menenggang (menghargai, membiarkan, membolehkan) pendirian (pendapat, pandangan, kepercayaan, kebiasaan, kelakuan, dsb.) yang berbeda atau bertentangan dengan pendirian sendiri. ${ }^{4}$ Menurut Tesaurus Bahasa Indonesia, toleransi adalah keterbukaan, pemaafan, penerimaan, pengertian, dan tenggang rasa. ${ }^{5}$ Toleransi juga sepadan dengan kata tasâmub. ${ }^{6}$ Adapun spiritual adalah adjektiva yang berhubungan dengan atau bersifat kejiwaan (rohani/batin). ${ }^{7}$ Tesaurus Bahasa Indonesia mengartikan spiritual sebagai kebatinan, kejiwaan, kerohanian dan psikis, sedangkan anonimnya adalah jasmaniah. ${ }^{8}$ Arti kebahasaan demikian bisa dijadikan dasar untuk menginferensi konsep-konsep dasar toleransi spiritual.

Pertama, objek toleransi spiritual ialah perbedaan atau pertentangan antar keyakinan atau kepercayaan. Objek demikian belum sepenuhnya membedakan toleransi spiritual dari toleransi perspektif lainnya yang juga memperlakukan perbedaan atau pertentangan keyakinan atau kepercayaan sebagai sebuah keniscayaan kehidupan bersama. Kedua, sikap toleransi spiritual bukan sikap menyeragamkan atau menyatukan perbedaan keyakinan atau kepercayaan, atau mensinkretisasikannya, melainkan menenggang rasa terhadap perbedaan atau pertentangan antar keyakinan atau kepercayaan tersebut. Jadi toleransi spiritual tetap mempertahankan prinsip-prinsip pluralis dan multikulturalis.

${ }^{4}$ Tim Penyusun Kamus Pusat Bahasa, Kamus Bahasa Indonesia, (Jakarta: Pusat Bahasa Departemen Pendidikan Nasional, 2008), h. 1722

${ }^{5}$ Tim Redaksi Tesaurus Bahasa Indonesia, Tesaurus Bahasa Indonesia (Jakarta: Departemen Pendidikan Nasional, 2008), h. 527

'Ibid., h. 499

${ }^{7}$ Ibid., h. 1503

8Ibid., h. 468 
Ketiga, toleransi spiritual dibentuk oleh dimensi-dimensi kebatinan atau keruhanian, seperti al-bubb (cinta), al-bâl ("kondisi spiritual"), al-maqâm ("kedudukan spiritual"), dan al-taraqqî ("pendakian spiritual"). Toleransi spiritual tentu saja tidak dengan sendirinya dihayati secara sama dan utuh, melainkan bervariasi dan penuh nuansa.

Faktor terpenting yang melatarbelakangi variasi toleransi spiritual ialah jenis pengalaman religius. Pengalaman religius biasanya terbentuk karena keterlibatan dan penghayatan seseorang terhadap ajaran keagamaan yang dianutnya. Intensitas dan pola pengalaman religius akan menentukan kualifikasi toleransi spiritual. Keterlibatan dan penghayatan religius yang berbeda-beda untuk setiap orang dan untuk, dalam pengertian tertentu, setiap komunitas keagamaan, akan mengakibatkan perbedaan toleransi spiritual. Setiap jenis dan pengalaman religius memiliki bobot toleransinya masing-masing.

\section{Toleransi Spiritual dalam Religiusitas}

Pada kalangan pemikir Islam, adalah Soroush yang pernah membuat klasifikasi jenis religiusitas. Membedakan jenis-jenis religiusitas, seperti diakui olehnya, bukanlah ide baru atau inovatif, karena al-Qur'an sendiri menawarkan cara untuk membedakan jenis religiusitas. Salah satu bukti yang diajukannya ialah adanya penggolongan ashâb al-yamîn (orang-orang kanan) dan al-sâbiqûn (orang-orang paling dulu) di dalam al-Qur'an. Soroush sendiri mengklasifikasi tiga jenis religiusitas. Ketiga jenis religiusitas yang dibuatnya akan dipinjam untuk mengkonstruksi posisi toleransi spiritual.

Pertama, religiusitas pragmatis. Religiusitas pragmatis memiliki beberapa sifat, antara lain dogmatis, ritualistik, ideologis, terikat identitas, kolektif, legalistik-yuristik, imitatif, dan tradisional. Ini merupakan religiusitas kalangan ulama dan para pengikutnya. Tugas pendidikan para ulama ialah mengajarkan religiusitas mereka kepada manusia. Moralitasnya adalah moralitas agama, sedangkan moralitas umumnya menempati posisi kedua. Religiusitas ini berupaya menemukan gerakan kebenaran, yang merupakan atribut ideologis, dan menyaksikan agama sebagai pelayan beragam aspek kehidupan, seperti pelayan sistem sosial dan politik. Kepribadian 
religiusnya berkarakteristik historis. Karena menekankan perbedaan dogmatis, maka religiusitas pragmatis menciptakan antara lain pembagian ideologis, pemilahan ahli surga dan neraka, persepsi Tuhan sebagai milik aliran sendiri, penyempitan definisi kebenaran dan perluasan definisi kepalsuan, identitas manusia sejati, penekanan untuk setiap detail perbedaan, dan pengkotak-kotakan manusia ke dalam perbedaan (kelompok, mazhab dsb.). ${ }^{9}$ Dalam religiusitas pragmatis, perbedaan dapat diterima apabila dijustifikasi melalui dogma atau tradisi yang dipegang secara ketat.

Seseorang atau sekelompok orang yang teridentifikasi memiliki kecenderungan religius pragmatis akan menyikapi perbedaan keyakinan atau kepercayaan secara normatif-formalistik. Toleransinya adalah toleransi bersyarat, sempit, dan menuntut kegunaan atau kemanfaatan praktis. Spirit yang diutamakan adalah penghormatan mutualis antar keyakinan atau kepercayaan. Toleransi yang ditandai oleh prinsip resiprokalitas semacam ini dapat dijumpai di berbagai komunitas keagamaan.

Kedua, religiusitas gnostik. Dalam religiusitas gnostik, seseorang menemukan rasionalitas yang sensitif terhadap ketepatan alasan untuk sebuah klaim (kebenaran, keyakinan, dsb.). Kalau religiusitas pragmatis bersifat dogmatis, maka religiusitas gnostik menimbulkan skeptis dan keheranan intelektualistik. Kalau religiusitas pragmatis bersifat kolektif, maka religiusitas gnostik bersifat individual, dan dipenuhi dengan refleksi dan revisi berkelanjutan. Oleh karena itu, religiusitas gnostik tidak stabil dan fluktuatif, menolak keseragaman atau penyeragaman, kritis, investigatif, dan independen dalam kebenarannya sendiri. Religiusitas individual yang tidak seragam itu identik dengan pluralisme konsepi dan interpretasi. Dalam Islam, menurut Soroush, teolog dan mufassir adalah dua wakil utamanya. ${ }^{10}$ Toleransi dapat diwujudkan apabila sebuah klaim kebenaran, keyakinan atau kepercayaan, dianggap sebagai bagian dari pluralitas konsepsi dan interpretasi yang bertanggung jawab.

"Abdol Karim Soroush, "Jenis-jenis Religiositas", Al-Huda Jurnal Kajian Ilmu-ilmu Islam, Vol. 2 No.4, 2001, h. 94-96.

10Ibid., h. 96-100. 
Dengan demikian, dalam religiusitas gnostik, kedalaman dan orisinalitas ilmu (al-ilm) atau pengetahuan (al-ma'rifah) identik dengan jalan (al-thariqab) yang paling tepat untuk mencapai toleransi. Dari agama, keyakinan atau kepercayaan, akan lahir pengertian-pengertian rasional dan tertuju kepada manusia sebagai individu bernalar. Proses penalaran yang berjalan seiring dengan proses individuasi religius itu akan membentangkan jembatan toleran antar keyakinan atau kepercayaan yang berbeda-beda.

Ketiga, religiusitas eksperiensial. Jika religiusitas pragmatis menuntut kegunaan praktis, religiusitas gnostik menuntut pengetahuan rasional, maka religiusitas eksperiensial menuntut bukti, penyaksian, penyingkapan, dan manifestasi. Karena pada dasarnya religiusitas ini bukanlah religiusitas instrumental, mental dan teoritis. Moralitas orang-orang berkeyakinan dengan pengalaman eksperiensial adalah moralitas cinta. Jika buah cinta adalah persatuan dan kebahagiaan, maka etiket cinta adalah kerahasiaan. Ini semua dimungkinkan karena Tuhan memahami semua perbedaan. Pluralitas pengalaman dan religius jelas merupakan masalah prinsip dan tak terelakkan. Oleh karena itu, religiusitas eksperiensial cenderung untuk damai (peace), individualistik, bergairah, dan intim. ${ }^{11}$ Dalam religiusitas eksperiensial, toleransi antar keyakinan atau kepercayaan justru untuk membuktikan atau menyaksikan kedamaian dan keintiman dengan-Nya. Presisi dogmatis dan argumen rasional bukan prasyarat mutlak toleransi.

Dalam religiusitas eksperiensial, alih-alih kontradiksi yang berperang terus-menerus, klaim-klaim keyakinan atau kepercayaan yang berbeda satu sama lain merupakan paradoks manifestasi kebenaran yang menggairahkan. Kendati dengan batasan-batasan tertentu, semua jenis religiusitas memiliki kesadaran bahwa perbedaan keyakinan atau kepercayaan adalah keniscayaan yang membutuhkan toleransi, namun toleransi spiritual lebih kuat bersarang pada jenis religiustitas eksperiensial. Manifestasi kebenaran harus dialami, dirasakan, dicintai dan diintimi. Religiusitas eksperiensial, seperti dapat diduga, tumbuh subur di

11Ibid., h. 100-102 
dunia tasawuf, entah yang filosofis (al-tashawnuf al-falsafi) maupun praktis (al-tashawnuf al-'amalì).

\section{Spiritualitas Manusia Toleran}

Kalangan sufi umumnya memandang kesejatian manusia tidak diperoleh secara material, fisikal, atau biologikal, melainkan secara immaterial, metasifik atau spiritualis. Benda-benda material, fisikal dan biologikal tak lebih dari sekedar artifisial ketimbang realitas sejati. Realitas sejati berada pada alam rohani atau batin, immaterial, dan metafisik. Inilah alam tertinggi yang harus dicapai oleh manusia. Adalah tidak berlebihan jikalau dikatakan bahwa tasawuf sebetulnya menyakini manusia memiliki kewajiban atau tanggung jawab spiritual. Tanggung jawab spiritual hanya bisa diemban dan ditunaikan oleh manusia yang membebaskan dirinya dari alam material, fisikal, biologikal, atau alam artifisial, dan menuju alam sejati.

Toleransi spiritual akan memandang manusia tentu bukan sebagai warga negara (citizen), sebagaimana toleransi liberal, yang kebebasan pilihan personalnya harus dihormati, melainkan sebagai imago Dei ("gambar Tuhan") seperti sering digunakan di kalangan teolog dan agamawan pada umumnya. Sebaliknya ke-ilâhiyah-an, yang secara harfiah berarti "berkarakteristik Tuhan", menurut istilah Ibn 'Arabi, adalah setiap nama-Nya yang disandarkan kepada manusia. ${ }^{12}$ Unsur ketuhanan pada manusia semacam ini juga membedakan toleransi spiritual dari toleransi lainnya. Pengandaian eksistensi Ilahi-manusiawi atau manusiawi-Ilahi bersifat fundamental dan substansial di kalangan sufi ternama, terlebih mereka yang memiliki kecenderungan filosofis. Para tokoh agama juga mempercayai pandangan tersebut. Magnis Suseno, misalnya, mengartikulasikan kembali pandangan Nurcholish Madjid (w 2005) tentang keharusan umat Islam untuk percaya kepada kemanusiaan. Madjid menegaskan bahwa percaya kepada Allah merupakan inti dan dasar agama Islam. Ini berarti, menurut Magnis Suseno

12Anwâr Fu'ad Abî Khazzâm, Mu'jam al-Mushthalahât al-Shîfiyah, (Beirut: Maktabah Lubnân Nâshirûn, 1993), h. 45 
“...iman kepada Allah hanya benar kalau terwujud dalam hormat terhadap manusia ciptaan tertinggi Allah."13 Memang benar ada kesulitan besar atau bahkan kesalahan serius jikalau iman kepada Allah dipisahkan dari percaya kepada manusia (seorang Nabi atau mursyid, misalnya).

Spiritualitas akan melihatkan kepada manusia tentang perbedaan-perbedaan sejati. Pertama-tama tentu saja perbedaan jarak dan kualitas "relasi" manusia dengan Tuhan. Perbedaanperbedaan sejati hanya bisa dilihat dengan optik spiritual, entah karena perbedaan al-maqâm maupun perbedaan al-bâl. Adapun perbedaan manusia secara biologis, kultural, sosial, ekonomi dan politik adalah perbedaan di alam artifisial; material dan fisikal. Bahkan, perbedaan menjalankan ritus keagamaan pun bisa dipandang sebagai perbedaan artifisial jikalau dijalankan tidak dengan cara dan tujuan yang semestinya. Optik manusia spiritualis akan memiliki kemampuan untuk menyibak kesejatian ritus-ritus keagamaan.

Perbedaan-perbedaan sejati yang dialami oleh manusia spiritualis memang berhak untuk dikatakan tidak dapat ditawartawar, karena perbedaan-perbedaan tersebut didasarkan pada pengalaman, penyaksian, keintiman, dan bukan sekedar interpretasi atau opini. Namun hal semacam ini, bagi Lings, justru mengawali kemusykilan tasawuf ${ }^{14}$ atau spiritual. Inti kemusykilan yang diajukan Lings akan dijelaskan nanti. Cukup dikatakan, bahwa spiritualitas akan meningkatkan manusia untuk menyaksikan perbedaanperbedaan sejati, hirarki realitas, dan membentuk sikap toleran di dalamnya.

Toleransi bagi kaum liberal adalah tanggung jawab sosial (sumbu horizontal) dan tanggung jawab bernegara (sumbu vertikal). Toleransi sosial akan berkembang sedemikian rupa apabila manusia memiliki sikap sosial yang inklusif. Sebaliknya, sikap eksklusif akan

${ }^{13}$ Franz Magnis-Suseno, SJ, "Agama, Kebangsaan dan Demokrasi: Nurcholish Madjid dan Kemanusiaan" dalam Franz Magnis-Suseno (dkk)., Agama, Keterbukaan dan Demokrasi, Harapan dan Tantangan, (Jakarta, Pusat Studi Agama dan Demokrasi Yayasan Paramadina bekerjasama dengan The Asia Foundation dan The Ford Foundation, 2015), h. 4-5

${ }^{14}$ Martin Lings, Ada Apa Dengan Sufi?, penerj. Achmad Maimun, (Yogyakarta: Pustaka Sufi, 2004), h. 123 


\section{Akmansyah}

menjauhkan manusia ke arah perlawanan terhadap toleransi. Semakin eksklusif manusia, semakin intoleran dia. Apakah implikasi yang sama dialami oleh seseorang yang menunaikan tanggung jawab spiritual? Bagaimana tanggung jawab sosial seorang manusia spiritualis? Karena tergolong religiusitas eksperiensial, manusia spiritualis mestinya inklusif: terbuka dan cinta damai.

Namun pengandaian sosial yang langsung bisa dinyatakan tanpa diskusi panjang ialah bahwa eksklusivitas, yang merupakan penyumbang perlawanan terhadap toleransi, ternyata bisa menjangkiti seseorang yang menapaki jalan spiritual. Ditinjau dari aspek doktrin atau dogma, eksklusivitas berkeyakinan atau berkepercayaan memang merupakan hak asasi. Setiap agama memiliki wilayah eksklusivitas yang tidak mungkin ditawar-tawar atau dinegosiasikan dengan apapun. Tasawuf, sebagai lahan subur pertumbuhan spiritual, selain memiliki inklusivitas, memiliki hak asasi yang sama. Dalam salah satu karyanya, Martin Lings menyediakan bab khusus untuk membahas apa yang disebutnya eksklusivitas tasawuf.

Mengikuti uraian Lings, eksklusivitas tasawuf (spiritual) bermula ketika manusia profan, istilah khusus yang digunakan Lings, memandang titik kesadaran individual sebagai 'Diri Tertinggi', sementara seluruh doktrin dan pengalaman-pengalaman para wali yang terekam secara tradisional, ditafsirkan demi kepuasan diri (ego) dan dianggap transenden oleh (sebetulnya) diskriminasi yang miskin intelektual. Manusia profan hanya menyadari sebagian jiwanya, sementara praktik-praktik mistik yang pertama kali tak jarang bukan menghantar pada pengalaman spiritual, melainkan pengalaman psikis saja. ${ }^{15}$ Lings sebetulnya ingin menegaskan bahwa manusia profan rentan terhadap eksklusivitas jikalau dia mengabsolutisasi kesadaran individual dan spiritual yang sebetulnya masih membutuhkan pendakian terus-menerus.

Toleransi manusia spiritualis, seperti sudah dijelaskan, adalah toleransi sejati mengenai perbedaan atau pertentangan. Pertentangan pertama yang dihadapi manusia spiritualis, seperti umum diketahui, ialah tarik-menarik antara kebaikan (al-khair) dan keburukan (al-syar) yang melekat pada jiwanya. Sebuah ayat al-

15Ibid., h. 127 
Qur'an menyebut jiwa manusia terilhami potensi al-fujûr ("pembangkangan") dan al-taqwâ ("ketakwaan") (Qs. al-Syams: 8). Istilah konflik batin seringkali harus dipahami sebagai konflik antara dua potensi kekuatan tersebut. Keburukan jiwa dirobohkan dengan cara membersihkan atau menjernihkan hati (al-qalb). Tanpa penjernihan hati, konflik batin akan selalu muncul. Hal ini berarti kegagalan toleransi spiritual.

Istilah lain yang digunakan untuk menggambarkan adanya pertentangan atau konflik batin pada manusia ialah jadal (harfiah: perdebatan, perbantahan, pertentangan) seperti dimaksudkan oleh Shahrûr. Menurutnya, manusia senantiasa menghadapi jadal yang khas dan tidak dijumpai pada selain dirinya sebagai insan (al-insân), yaitu jadal al-fiker (“dialektika pikiran"), karena hanya manusia saja, melalui akalnya, yang mampu berpikir. Inilah penyebab al-Qur'an menyebut manusia sebagai sesuatu yang paling banyak jadal (Qs. alKahfi: 54). Prinsip yang mendasari jadal dan pengetahuan manusia ialah pembedaan antara kebenaran (al-haq) dan kebatilan (al-bâthil), atau antara hakikat (al-haqîqah) dan imajinasi (al-wahm). Hal ini, menurut Shahrûr, berjalan secara dialektis ('alâqah jadaliyab). ${ }^{16}$ Kesanggupan untuk membedakan atau memisahkan hakikat dari imajinasi menjadi dasar pengetahuan kemanusiaan (al-ma'rifah al-

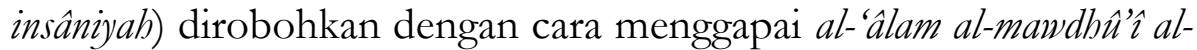
rahmânî ("alam objektif yang berkarakteristik kasih-sayang") atau hakikat. ${ }^{17}$ Ketidakmampuan membedakan atau memisahkan hakikat dari imajinasi mengindikasikan manusia masih mengalami konflik batin. Hal ini berarti kegagalan toleransi spiritual.

\section{E. Spiritual Sufistik, Sekolah Toleransi}

Selain menampilkan sikap asketik, tasawuf juga merupakan lembaga pendidikan yang memberikan bimbingan kepada manusia menuju keharmonian dan keseimbangan secara total. Tasawuf yang pada mulanya merupakan kegiatan yang bersifat individual atau personal (zubd) kemudian berkembang pula dalam bentuk kelompok sosial atau tarekat (taríqah) dalam lingkup zäwiyah, khān

${ }^{16}$ Muhammad Shahrûr, Al-Kitâb wa al-Qur'ân Qirâ'ah Mu'ashirah, (Damaskus: Al-Ahâlî li al-Thibâ'ah wa al-Nashr wa al-Tawzî', 1990), h. 251

${ }^{17}$ Ibid., h. 252 
(khānaqāh) ${ }^{18}$ atau ribäth (rabth), yang kemudian dikenal sebagai tempat-tempat (lembaga) pendidikan khusus kalangan sufi. ${ }^{19}$

Tujuan pendidikan spiritual sufistik diantaranya adalah untuk mencari, membina dan mengembangkan hubungan individualvertikal yang harmonis; sampai (wushül) kepada Allah, melaksanakan moralitas Islam yang diteladani oleh Nabi Mubammad $S A W$ berdasarkan pada cita-cita ideal dalam al-Qur'an. Pada kondisi sampai (wushül) kepada Drat Yang Haq, maka Allah akan membersibkan, menyucikan, serta memilihnya. Dia mencintainya dan menjadikan kecintaan dalam dirinya kepada selurub makbluk-Nya. ${ }^{20}$ Namun, menurut Seyyed Hossein Nasr, usaha tersebut akan sia-sia dan tidak akan berfaedah, kecuali jika guru itu hadir bersama murid yang akan diajarinya. Tanpa batu filosof, menurut Nasr, tak mungkin ada perubahan alkimia. ${ }^{21}$

Perjuangan (lahir-batin) yang akan ditempuh oleh seorang murid dalam menempuh tahapan-tahapan untuk bisa wushül kepada Allah. Derajat, posisi, dan tingkatan seorang hamba di hadapan Allah, mutlak ditentukan oleh kesungguhannya di dalam ibādah, riyāahah dan mujāhadah. Ajaran maqāmāt dan abwāl yang merupakan tahapan-tahapan spiritual yang mesti dilalui murid, seperti tobat, zuhud, tawakal, sabar, ridha dan seterusnya. Tahapan-tahapan tersebut dipabami dan diberi makna selaras dengan cita penyucian batin versi spiritual tasawuf.

Tasawuf, terutama wijudiyyah, mengajarkan toleransi, moderasi, hidup berdampingan secara damai dan nilai-nilai kemanusiaan. Hal itu dimungkinkan karena pemahaman metafisisnya menyiratkan bahwa ada persatuan (unity) dan kesatuan (oneness) di semua yang ada. Segala perbedaan, perpecahan dan semua yang ada, adalah merupakan ilusi. Selain itu, dalam pemahaman mereka, makna toleransi melampaui makna eksoteris dan menyentuh sisi esoteris kemanusiaan yang lebih dalam. Yaitu persaudaran sesama manusia (al-ukhumwah al-basyariyah), cinta

18Pusat pendidikan Sufi. Lihat "Glossary" dalam Seyyed Hossein Nasr (ed), Islamic Spirituality: Foundations,(New York: Crossroad, 1987), h. 420

${ }^{19}$ Turkish: tekke, tekye; Arabic zäwiyah, pl. zawāyā; Persian dargāh. khānaqāh dan khānaqāh. Lihat http://wiki.phantis.com/index.php

20 'Abd al-Qädir al-Jìlāni, Futūn al-Ghaib, I'tanā bih wa haqqaqahu Abū Sahl Najāh 'Audh Shiyām, (Al-Qāhirah: Dār al-Muqaththam lī al-Nasyr wa alTauzì , 2007), h. 112

${ }^{21}$ Seyyed Hosein Nasr, Sufi Essays, (Albany, NY: Suny, 1972), h. 58 
kosmik (al-mahabbah al-kauniyyab), kasih ketuhanan (al-isyq alrabbânî), moral memaafkan (al-'afiv al-akblâqî), budaya memaafkan (al-shafh al-hadhâri), yang merujuk pada kesatuan agama, akidah dan penyembahan. Terlepas dari perbedaan-perbedaan prinsip, kaidah, rukun, tujuan bahkan aspek formalitasnya. Satu-satunya tujuan adalah menyembah Allah SWT, ketaatan kepada-Nya secara totalitas. Toleransi tersebut didasarkan pada penerimaan terhadap yang lain, apa pun kewarganegaraan, agama, etnis, keyakinan, bahasa, warna kulit, kelas sosial, kasta, politik, atau sektarian. Semua dan sekte dan ritual-ritual adalah satu dalam perspektif manusia sufi, selama tujuan adalah cinta ilahi dan untuk mencapai cinta ilahi. ${ }^{22}$

Manusia spiritualis, seperti juga kalangan sufi dan umat Islam pada umumnya, tentu saja akan menjauhkan diri dari perbuatan syirik (sekutu Tuhan). Syirik jelas bertentangan secara diametral dengan ajaran tauhid (keesaan Tuhan). Berpegang teguh pada tauhid adalah bagian dari tanggung jawab spiritual. Namun demikian, orang-orang yang melakukan syirik (musyrik) tampil dalam berbagai macam bentuk. Salah satunya digambarkan alQur'an sebagai orang-orang yang memecah belah agama, dan setiap pecahan justru merasa bangga. Sebelum itu, al-Qur'an lebih dulu menyebutkan bahwa dengan fithrat (fitrah) Allah telah menciptakan manusia menurut fitrah tersebut, dan tiada perubahan bagi ciptaan Allah, justru demikian merupakan agama yang lurus.

"Maka hadapkanlah wajahmu dengan lurus kepada agama Allah, fitrat Allah yang telah menciptakan manusia menurut fitrat tersebut. Tiada perubahan pada penciptaan (fitrat) Allah. Itulah agama yang lurus, tetapi kebanyakan manusia tidak mengetahui. Kembali bertaubat, bertakwahlah kepada-Nya, dirikan shalat, dan janganlah kalian tergolong orang-orang musyrik. Yaitu orang-orang yang memecah-belah agama mereka, dan mereka menjadi kelompok-kelompok, setiap golongan bangga dengan apa yang ada pada mereka" (Qs. Ar-Rūm: 30-32) 23

22Jamīl Hamdāwī, al-Tasāmuh al-Shūfì wa al-Ṭuruq al-Magrib, dalam http://almothaqaf.com/index.php/toleration/17493.html, diakses tanggal 11 November 2016

23Bandingkan dengan terjemahan (tafsir?) sebagai berikut: "Wahai Muhammad, teguhkanlah hatimu mengikuti Islam sebagai ciptaan Allah. Allah 
Memecah belah agama mengandaikan intoleransi terhadap perbedaan yang sangat sulit dielakkan dalam beragama, sedangkan berbangga-bangga terhadap perpecahan kelompok mencerminkan sikap diskriminatif dan eksklusif yang ekstrim. Memecah belah agama, yang merupakan tabiat orang-orang musyrik, dipertentangkan dengan agama yang lurus (al-dîn al-qayyim). Perbuatan syirik "sosial" semacam itu juga bertentangan dengan toleransi spiritual yang justru melihat atau menyaksikan perbedaan keyakinan atau kepercayaan sebagai harmoni yang menggairahkan. Jika syirik dapat mengambil bentuk intoleransi, maka tauhid justru sebaliknya. Tepat sekali apabila Rasulullah menyatakan: "Dua hal yang tidak boleh didekati; musyrik kepada Allah dan mencelakakan orang lain." 24

Konsep lain yang diperkenalkan al-Qur'an untuk menggambarkan penyebab perpecahan (intoleransi) adalah baghy (kedengkian). Kedengkian adalah penyakit hati. Manusia spiritualis jelas akan menjauhi dan berupaya terus memusnahkan penyakitpenyakit hati.

"Dan mereka tidak berpecah belah kecuali setelah datang pada mereka ilmu, karena baghy di antara mereka. Kalau bukan karena ketetapan dari Tuhanmu hingga waktu yang ditentukan, maka pastilah mereka sudah dibinasakan. Dan orang-orang yang

ciptakan manusia sesuai dengan ajaran agama Allah. Tidak ada yang berubah dalam ciptaan Allah. Islam itu adalah agama yang benar. Akan tetapi sebagian besar manusia tidak mau menyadari kebenaran Islam." Wahai manusia, bertaubatlah kalian kepada Allah, taatlah kepada-Nya, dan laksanakanlah shalat. Janganlah ada di antara kalian yang menjadi orang musyrik" yaitu orang-orang yang menukar keyakinan tauhid dengan kepercayaan banyak tuhan. Kaum musyrik berpecah-belah menjadi beberapa kelompok agama. Masing-masing kelompok mengaku dirinya benar, sedangkan kelompok lain sesat." Muhammad Thalib (penerj.), Al-Qur'an Tarjamah Tafsiriah Memahami Makna al-Qur'an Lebih Mudah, Cepat dan Tepat, (Yogyakarta: Ma'had An-Nabawy Markaz Pusat Majelis Mujahidin, 2012), h. 507

${ }^{24}$ Hadis dikutip dari Muhammad Mahmud Abdul Alim, Jalan Rubani Para Wali dalam Mencapai Makrifat dan Kebersiban Hati, penerj. Ahmad Syakirin, (Jakarta: Al-Mawardi Prima, 2003), h. 60 
diwariskan al-kitab sesudah mereka benar-benar berada dalam keraguan lagi bimbang tentang al-kitab itu." (Qs. al-Syūra: 14)25

Sebagaimana halnya kebutuhan kaum sufi untuk mendidik dan mengembangkan kualitas spiritualnya, toleransi spiritual membutuhkan metode penempaan ruhani (al-riyạ̈dah). Toleransi spiritual bukan pembawaan antropologis, sosial atau apalagi politis, yang dengan begitu saja tumbuh berkembang setelah seseorang menyatakan beriman atau berkeyakinan. Pendidikan spiritual dimulai dengan mawas diri dari perbuatan syirik yang berimplikasi pada perpecahan (intoleransi) atau mencelakakan orang lain seperti diperingatkan Rasulullah SAW. ${ }^{26}$ Metode al-riyạ̈ab pada intinya ialah penyucian akhlak, entah dengan (1) keluar dari kebiasaan jiwa (buruk) atau disebut al-riyạạah al-adab, maupun dengan (2) memvalidisi tujuan al-riyädah, yaitu Allah, atau disebut al-riyạ̈dah alțalab, seperti dikemukakan oleh sufi-sufi ternama seperti Al-Gazālī (w 505) dan Ibn 'Arabī. ${ }^{27}$ Jiwa manusia toleran perspektif spiritual adalah jiwa yang bersih dari berbagai macam penyakit, terutama kedengkian terhadap sesama, dan berusaha terus mendekatkan diri kepada-Nya (taqarrub ilā Allāh).

Metode lain yang diimplementasikan dalam pendidikan spiritual sufistik dalam mengembangkan toleransi spiritual ialah dengan kesungguhan untuk melakukan al-mujāhadah, entah

${ }^{25} \mathrm{Ada}$ pula yang menerjemahkan (menafsirkan?) ayat ini lebiih sebagai kritik pedas yang semata-tama tertuju kepada pemeluk agama lain. "Setelah Muhammad sebagai Rasul Allah datang kepada kaum Yahudi dan Nasrani membawa bukti kebenaran kerasulannya, mereka berpecah-belah, sebagian menentang dan sebagian lain menerimanya. Orang-orang yang menentang semata-mata karena rasa dengki kepada rasul mereka. Wahai Muhammad, sekiranya Tuhanmu dahulu belum menetapkan waktu tertentu turunnya adzab kepada suatu kaum, tentulah adzab itu segera diturunkan kepada mereka. Sesungguhnya umat Yahudi dan Nasrani yang telah mewarisi Taurat dan Injil, mereka selalu meragukan kebenaran Al-Qur'an". Muhammad Thalib (penerj.), Op. Cit., h. 613

${ }^{26}$ Hadits-hadits tentang larangan syirik dan menyakiti orang lain tersebar dalam khazanah hadits Nabi, seperti hadits 7 dosa-dosa besar :Syirik kepada Allah, Sihir, Membunuh Orang, Riba, Memakan Harta Yatim, Memfitnah Orang.....Hadits riwayat Bukhari, Shahih Bukhari, no. hadits 2615, (Beirut:Dar Ibnu Katsir, 1987) 3, hal 1017.

${ }^{27}$ Anwâr Fu'ad Abî Khazzâm, Op. Cit., h. 93 
mujāhadah al-nafs ("memerangi nafsu buruk") maupun mujāhadah alshaytān ("memerangi godaan setan"). ${ }^{28}$ Kesungguhan ber-mujāhadah akan memberikan implikasi signifikan terhadap toleransi spiritual. Menurut al-Jīlānī (w 1166), salah satu sifat yang harus dimiliki oleh ahli mujâhadah yang mencapai derajat mulia adalah “... berbaik sangka dengan muslimin dan tidak mudah menuduh mereka sebagai kafir atau munafik...". Jika seseorang tidak tergolong ahli mujāhadah, maka ia tidak menemukan apapun dalam tarekat. ${ }^{29}$ Jelas kiranya, berbaik sangka dan tidak mudah menuduh kafir atau munafik kepada orang lain adalah ciri-ciri toleran.

Toleransi spiritual dapat diprakarsai oleh pendidikan spiritual sufistik atau tarekat tertentu. Menurut Mulyadi Kertanegara, setelah abad kesebelas, tarekat memiliki peranan penting. Tarekat tidak hanya menambah dimensi emosional dan spiritual kepada sistem formal ibadah, melainkan pula menambah keintiman kehidupan sosial, perdagangan, lembaga keuangan dan kredit. Oleh ahli-ahli tarekat, jiwa-jiwa diangkat ke realitas jenjang tertinggi, ditunjuki dan didukung dengan kebutuhan sosial, politik dan ekonomi keseharian. ${ }^{30}$ Catatan penting dari pengalaman cemerlang tarekat itu ialah menambah keintiman kehidupan sosial. Telah disebutkan di atas, bahwa keintiman vertikal (manusiaTuhan) merupakan pengalaman religiusitas eksperiensial. Sekarang perlu ditambahkan, bahwa tarekat akan mempertebal kepekaan bertanggung jawab secara sosial pada manusia toleran perspektif spiritual tasawuf.

Telah pula disebutkan di atas, bahwa toleransi spiritual yang dilatarbelakangi oleh religiusitas eksperiensial berkarakteristik individual atau personal. Sekarang perlu ditambahkan, bahwa

${ }^{28}$ Ibid., h. 155

29Sifat-sifat lain ahli mujāhadah yang disebutkan 'Abd Al-Qādir al-Jīlānī adalah meninggalkan sumpah sama sekali, manjauhi bohong baik ketika serius ataupun gurau, tidak mengingkari janji, tidak menyakiti orang lain, menahan perbuatan sewenang-wenang kepada orang lain dan menjauhi diri dari provokasi untuk berbuat zalim, mencegah indera dari perbuatan maksiat, tidak meminta sesuatupun dari orang lain dan tidak memerlukan mereka, menjaga ketamakan nafsu dan terus berhubungan dengan Allah, dan terakhir tawâdlu. Muhammad Mahmud Abdul Alim, Op. Cit., h. 47

${ }^{30}$ Mulyadhi Kartanegara, Menyelami Lubuk Tasawuf, (Jakarta: Penerbit Erlangga, 2006), h. 242 
toleransi spiritual yang diamalkan dan dikembangkan oleh pendidikan spiritual sufistik atau tarekat tertentu akan menambahkan karakteristik lain. Hal ini, seperti dikatakan Ni’am, pada mulanya tarekat memang dijalankan secara individual, tetapi pengajaran-pengajarannya kemudian berkembang menjadi kebutuhan publik. ${ }^{31}$ Jadi toleransi spiritual bisa diinisiasi secara kolektif, kendati pengalamannya adalah pengalaman yang tetap saja subjektif.

\section{F. Penutup}

Toleransi spiritual mengandaikan toleransi yang mengakar atau berasal dari pengalaman rohani atau batin seseorang yang beragama, misalnya Islam. Seiring dengan disorientasi makna manusia modern, toleransi spiritual bermaksud mengembalikan makna terdalam dan orisinal dari perbedaan agama, keyakinan atau kepercayaan. Toleransi spiritual jelas bukan diderivasi dari doktrin negara liberal atau produk masyarakat pluralis dan multikulturalis, melainkan lebih sebagai konsekuensi atau tuntutan dari pengalaman religiusitas yang sejati. Oleh karena itu, toleransi spiritual relevan untuk diusulkan sebagai alternatif penyelesaian wabah intoleran antar umat beragama, berkeyakinan atau berkepercayaan di Indonesia dewasa ini. Dasar empiris, sosiologis, dan historisnya jelas, yaitu bangsa Indonesia adalah bangsa religius.

Pengembangan toleransi melalui pendidikan spiritual sufistik yang diusulkan memang baru sebatas konsep atau gagasan awal yang menantang kritik dan analisis lebih lanjut. Akan tetapi, patut disadari bahwa spitualitas sufistik bukanlah sesuatu yang aneh dan ajaib bagi bangsa Indonesia. Sebagian dari umat beragama di negeri ini telah lama mempraktekkannya, namun belum dikelola dan diinvestasikan sebagai modal toleransi spiritual. Padahal toleransi ini berguna untuk meredam konflik yang disertai tindak kekerasan, yang masih bermunculan dewasa ini akibat wabah intoleransi antar agama, keyakinan atau kepercayaan, menyebar luas. []

31Syamsun Ni'am, Tasawuf Studies Pengantar Belajar Tasawuf, (Yogyakarta: Ar-Ruzz Media, 2014), h. 213 


\section{DAFTAR PUSTAKA}

'Abd al-Qādir al-Jīlānī, Futūḥ al-Gaib, I'tanā bih wa ḥaqqaqahu Abū Sahl Najāḥ 'Audh Șiyām, Al-Qāhirah: Dār al-Muqaț̣am lī alNasyr wa al-Tauzì', 2007.

Franz Magnis Suseno SJ. (dkk), Agama, Keterbukaan dan Demokrasi, Harapan dan Tantangan. Jakarta, Pusat Studi Agama dan Demokrasi Yayasan Paramadina bekerjasama dengan The Asia Foundation dan The Ford Foundation, 2015

Galeotti, Anna Elisabetta. Toleration As Recognition. Cambridge: Cambridge University Press (Virtual Publishing), 2003

Horton, John dan Susan Mendus, "Introduction" dalam John Horton dan Susan Mendus (eds), Aspects of Toleration Philosophical Studies. London and New York: Methuen, 1985

Khazzâm, Anwâr Fu'ad Abî. Mu'jam al-Mushthalabât al-Shûfiyah. Beirut: Maktabah Lubnân Nâshirûn, 1993

Lings, Martin. Ada Apa Dengan Sufi?, penerj. Achmad Maimun. Yogyakarta: Pustaka Sufi, 2004

Muhammad Mahmud Abdul Alim, Jalan Rubani Para Wali Dalam Mencapai Makrifat dan Kebersiban Hati, penerj. Ahmad Syakirin. Jakarta: Al-Mawardi Prima, 2003

Muhammad Thalib (penerj.), Al-Qur'an Tarjamah Tafsiriah Memahami Makna Al-Qur'an Lebih Mudah, Cepat dan Tepat. Yogyakarta:

Ma'had An-Nabawy Markaz Pusat Majelis Mujahidin, 2012

Mulyadhi Kartanegara, Menyelami Lubuk Tasawuf. Jakarta: Penerbit Erlangga, 2006

Nicholson, R.A. Tasawuf Cinta Studi atas Tiga Sufi: Ibn Abi al-Khayr, al-Jili, Ibn al-Farid, penerj. Uzair Fauzan. Bandung: Mizan, 2003.

Seyyed Hosein Nasr, Sufi Essays, Albany, NY: Suny, 1972 , Islamic Spirituality: Foundations, New York: Crossroad, 1987

Shahrūr, Muhammad. Al-Kitāb wa al-Qur'ān Qirāah Mu'așșirah. Damaskus: Al-Ahālī li al-Ṭibā'ah wa al-Nașr wa al-Tawzì̄, 1990.

Syamsun Ni'am, Tasawnf Studies Pengantar Belajar Tasawuf. Yogyakarta: Ar-Ruzz Media, 2014 
Tim Penyusun Kamus Pusat Bahasa, Kamus Bahasa Indonesia. Jakarta: Pusat Bahasa Departemen Pendidikan Nasional, 2008

Tim Redaksi Tesaurus Bahasa Indonesia, Tesaurus Bahasa Indonesia. Jakarta: Departemen Pendidikan Nasional, 2008

\section{Jurnal:}

Soroush, Abdol Karim. "Jenis-jenis Religiositas", Al-Huda Jurnal Kajian Ilmu-ilmu Islam, Vol 2 No.4, 2001

\section{Internet:}

Soekarno, "Lahirnya Pancasila: Pidato Pertama Pancasila Diucapkan Bung Karno di Depan Dokuritu Zyunbi Tyoosakai Tanggal 1 Juni 1945” http://www.gmni.or.id/mediafiles/download/LAHIRNYA PANCASILA Pidato Pertama Pancasila Diucapkan Bu ng Karno di Depan Dokuritu Zyunbi Tyoosakai 1 Juni 1945 